\title{
Penggunaan Analytical Hierarchy Process Untuk Sistem Pendukung Keputusan Bantuan Siswa Miskin
}

\author{
Umar Wirahadi Kusuma \\ Jurusan Teknik Informatika, Fakultas Teknik, Universitas Wahab Hasbuloh. \\ Jl. Garuda No. 9 Tambak Beras Jombang \\ E-mail: umarwirahadikusuma74@gmail.com
}

\begin{abstract}
Abstrak-Dalam kehidupan saat ini teknologi semakin canggih dan berkembang pesat dibidang Teknologi Informasi. Komputer saat ini bukanlah suatu hal yang asing lagi, tapi sudah menjadi kebutuhan bagi banyak orang. Adanya computer bisa membantu atau mempermudah segala bentuk kebutuhan manusia akan informasi dan teknologi. Sekolah saat ini hamper semua administrasi dan keuangan dibantu oleh computer. Bahkan juga untuk pemberian Bantuan Khusus Siswa Miskin (BKSM) saat ini banyak yang sudah menggunakan computer. Hanya saja pengelolaan BKSM saat ini yang belum terakumulasi menggunakan database secara optimal, menyebabkan kesulitan dalam pemrosesan data yang menyebabkan lamanya proses penentuan penerimaan BKSM.

Hasil dari system pendukung keputusan atau prediksi diambil dari factor-factor yang mempengaruhi prestasi belajar siswa, yaitu keadaan keluarga, keadaan kesehatan orang tua, penghasilan orang tua, Jumlah keluarga yang ditanggung yang masih sekolah, dan prestasi yang dimiliki siswa. Kriteria- kriteria tersebut akan digunakan sebagai pertimbangan, bobot penilaian tertinggi yang didapat diasumsikan sebagai alternative terbaik, sehingga akan muncul dalam bentuk data prioritas (rangking).

Sistem Pendukung Keputusan ini menggunakan metode Analytical Hierarchy Process (AHP) untuk menyelesaikan permasalahan tersebut. Dengan adanya system SPK BKSM akan mempermudah dan mempercepat pengambilan keputusan. Dengan system yang dapat mempercepat pengambilan keputusan ini juga akan meningkatkan kualitas keputusan dalam menentukan siswa yang berhak menerima BKSM. Sistem ini hanya bersifat sebuah rekomendasi sebuah keputusan kepada pihak sekolah, untuk proses selanjutnya tetap tergantung pada sekolah yang bersangkutan.
\end{abstract}

Kata Kunci-SPK, BKSM, AHP

Abstract - In today's life of technology increasingly sophisticated and growing rapidly in the field of Information Technology. Computers today are not a strange thing anymore, but it has become a necessity for many people. The existence of a computer can help or facilitate all forms of human needs for information and technology. The current school is almost all administrative and financial aided by the computer. Even for the provision of Special Assistance for Poor Students (BKSM) today many are already using the computer. It's just that the current BKSM management that has not been accumulated using the database optimally, causing difficulties in data processing that causes the long process of determining the acceptance of BKSM.

The results of decision support systems or predictions are derived from factors affecting student achievement, ie family circumstances, parental health conditions, parent income, the number of underwritten families who are still in school, and student achievement. These criteria will be used as a consideration, the highest rated weight is assumed to be the best alternative, so it will appear in the form of priority data (rank).

Decision Support System uses the Analytical Hierarchy Process (AHP) method to solve the problem. With the system SPK BKSM will facilitate and speed up decision making. With a system that can accelerate decision-making this will also improve the quality of decisions in determining the eligible students receive BKSM. This system is only a recommendation of a decision to the school, for the next process still depends on the school concerned.

Keywords-SPK, BKSM, AHP 


\section{PENDAHULUAN}

Dalam kehidupan saat ini teknologi semakin canggih dan berkembang pesat dibidang Teknologi Informasi. Komputer saat ini bukanlah suatu hal yang asing lagi, tapi sudah menjadi kebutuhan bagi banyak orang. Adanya computer bisa membantu atau mempermudah segala bentuk kebutuhan manusia akan informasi dan teknologi. Sekolah saat ini hamper semua administrasi dan keuangan dibantu oleh computer. Bahkan juga untuk pemberian Bantuan Khusus Siswa Miskin (BKSM) saat ini banyak yang sudah menggunakan computer. Hanya saja pengelolaan BKSM saat ini yang belum terakumulasi menggunakan database secara optimal, menyebabkan kesulitan dalam pemrosesan data yang menyebabkan lamanya proses penentuan penerimaan BKSM.

Sistem Pendukung Keputusan (SPK) merupakan salah satu system yang digunakan banyak orang untuk membantu dalam pengambilan keputusan yang akurat dan efisien. Karena faktanya dilapangan banyak system pemberian beasiswa yang masih berorientasi subjektif. SPK berorientasi pada kriteria- kriteria yang yang dibuat, sehingga sangat minim hasil secara subjektif. Kriteriakriteria yang digunakan mengambil dari factor yang mempengaruhi prestasi belajar siswa, yaitu keadaan keluarga, keadaan kesehatan orang tua, penghasilan orang tua, Jumlah keluarga yang ditanggung yang masih sekolah, dan prestasi yang dimiliki siswa. Kriteria- kriteria tersebut akan digunakan sebagai pertimbangan, bobot penilaian tertinggi yang didapat diasumsikan sebagai alternative terbaik, sehingga akan muncul dalam bentuk data prioritas (rangking).

Sistem Pendukung Keputusan ini menggunakan metode Analytical Hierarchy Process (AHP) untuk menyelesaikan permasalahan tersebut. Dengan adanya system SPK BKSM akan mempermudah dan mempercepat pengambilan keputusan. Dengan system yang dapat mempercepat pengambilan keputusan ini juga akan meningkatkan kualitas keputusan dalam menentukan siswa yang berhak menerima BKSM. Sistem ini hanya bersifat sebuah rekomendasi sebuah keputusan kepada pihak sekolah, untuk proses selanjutnya tetap tergantung pada sekolah yang bersangkutan.

\section{METODE PENELITIAN}

3. a. flowchat Sistem

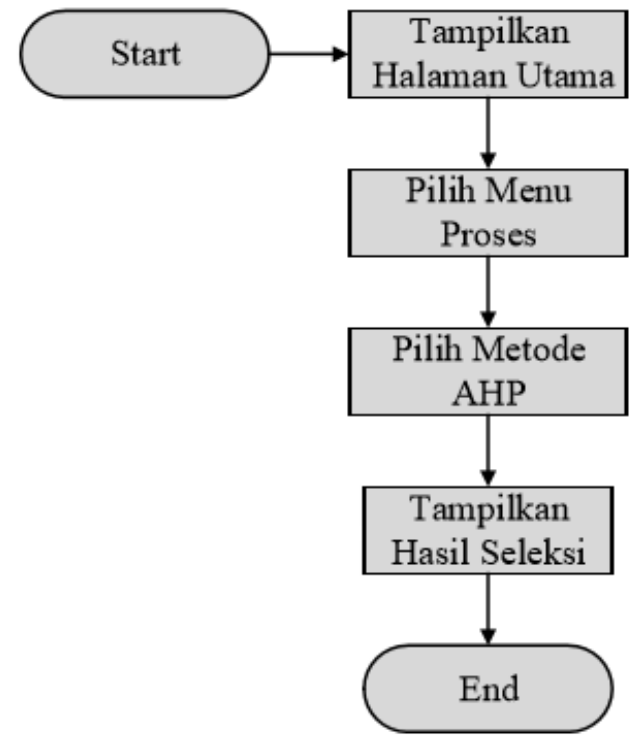

Gambar 1 flowchart sistem

Pada gambar 1 di atas dapat dijelaskan ketika aplikasi di jalakan yang pertama aplikasi menapilkan halaman utama, setelah itu pilih menu proses. Dalam menu proses ini, di dalamnya terdapat inputan kriteria yang digunakan untuk selanjutnya diproses menggunakan metode AHP. Kemudian pilih metode AHP dan menmpilkan hasil seleksi dari Sistem Pendukung Keputusan BKSM. 
b. Context Diagram.

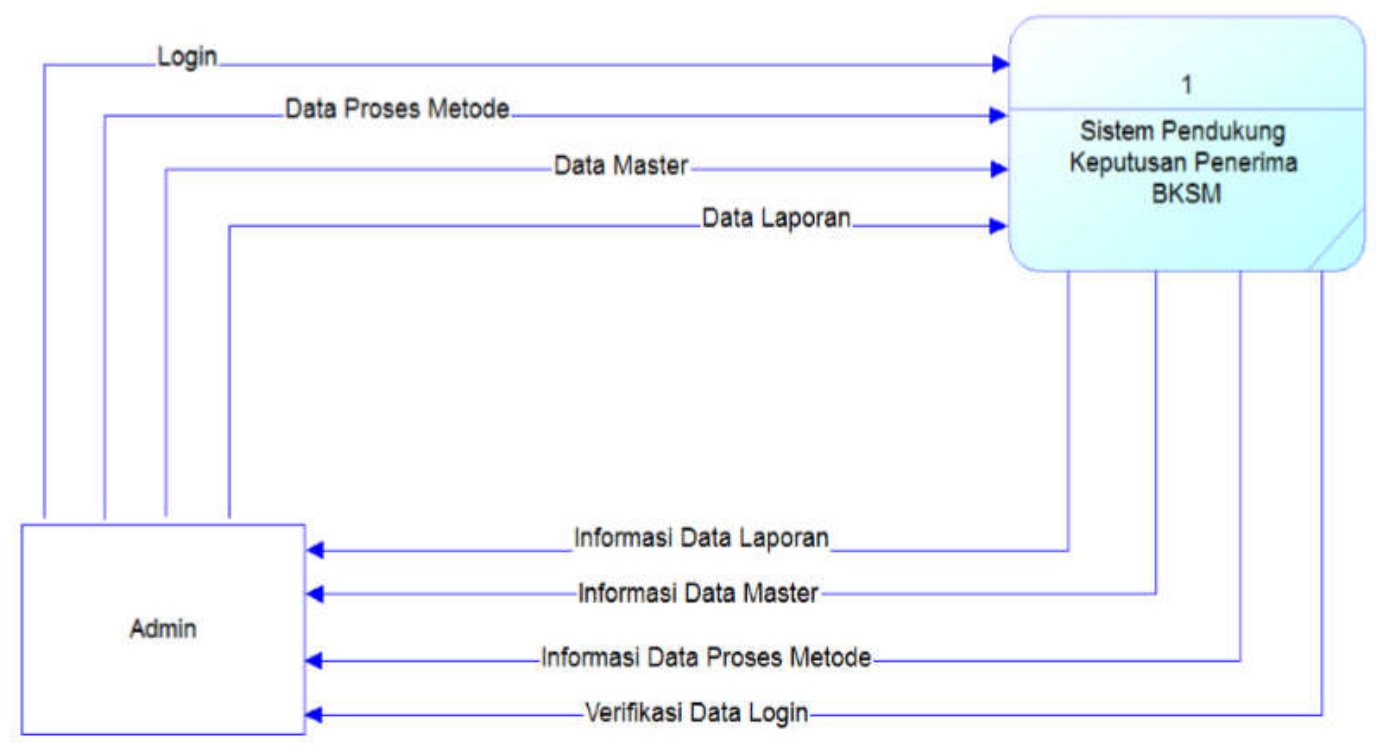

Gambar 2 Context Diagram

Dari gambar 2 di atas dapat di jelaskan Context Diagram merupakan diagram yang menggambarkan tentang Desain aplikasi sistem pendukung keputusan penerima BKSM secara keseluruhan. Pada Context Diagram dijelaskan bahwa aplikasi sistem pendukung keputusan memiliki satu entitas yaitu admin, pada halaman sistem admin memiliki hak akses untuk mengelola data kriteria dan nilai kriteria.

c. Data Flow Diagram (DFD) Level 1 


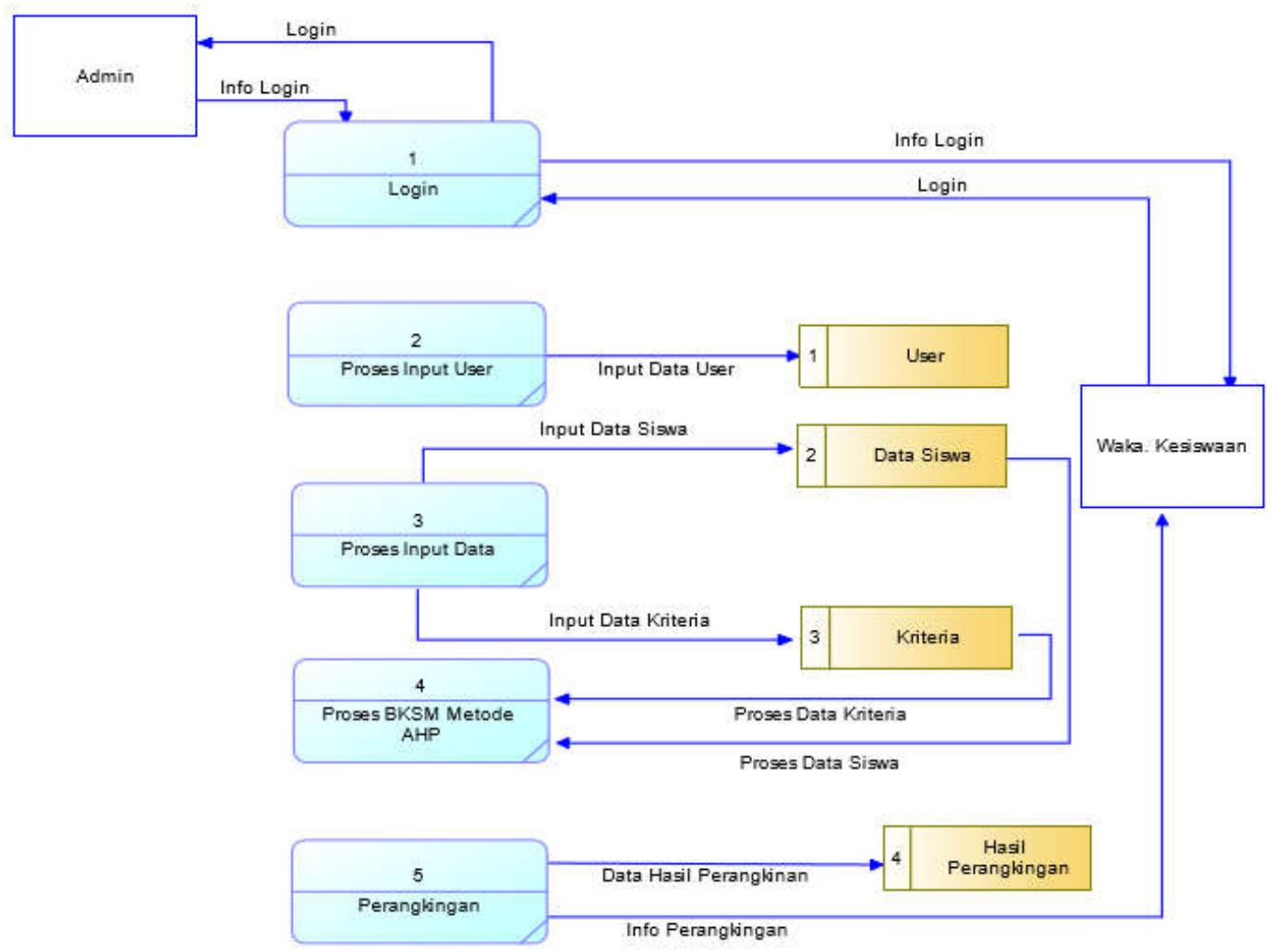

Gambar 3 Data Flow Diagram Level 1

DFD Level I terlihat pada gambar 3 menggambarkan alur dari aplikasi sistem pendukung keputusan penerima BKSM. pada rancangan dfd level 1 dapat dijelaskan bahwa admin harus melakukan login dengan cara memasukkan username dan password terlebih dahulu untuk dapat memasuki dan mengelola halaman aplikasi Sistem Pendukung Keputusan Penerima BKSM, setelah proses login aplikasi sistem akan melakukan pengecekan pada database "user" jika username dan password salah maka user harus mengulang memasukkan username dan password yang benar, tetapi apabila username dan password sudah benar maka admin dapat melanjutkan masuk pada halaman aplikasi sistem. Admin pada aplikasi tersebut dapat mengelola data master, data proses, data laporan.

\section{d. Data Flow Diagram (DFD) Level 2}

DFD Level 2 Proses data Siswa, admin dapat menambahkan, mengubah, dan juga menghapus data kriteria Siswa. Hasil dari data yang telah di tambahkan akan langsung disimpan pada database "bksm", jika admin melakukan perubahan pada data tersebut maka hasil perubahan data tersebut akan secara langsung tersimpan kembali setelah di perbarui. Untuk detail rancangan DFD Level 2 proses data siswa dapat dilihat pada Gambar 4. 


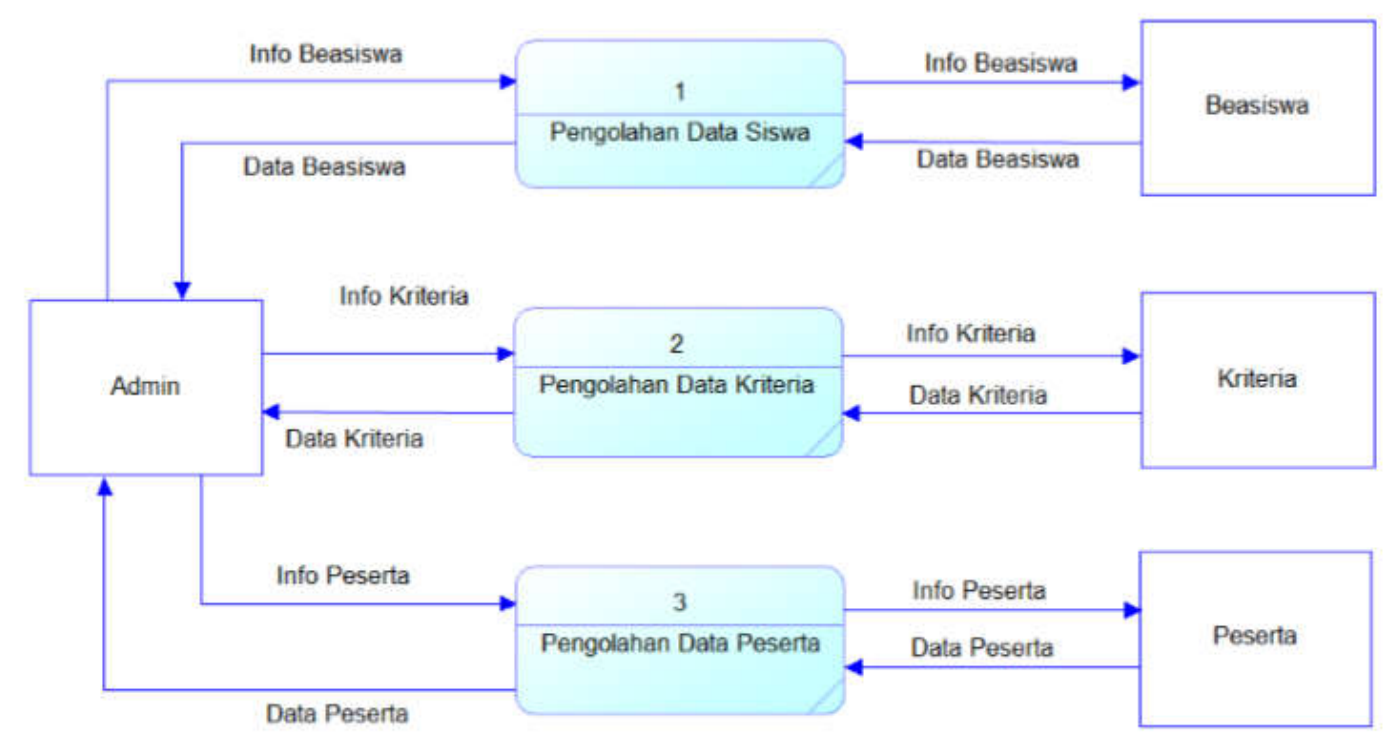

Gambar 4 Data Flow Diagram Level 2 Proses Siswa

e. Conceptual Data Model (CDM)

Berikut ini adalah Conceptual Data Model (CDM) yang memaparkan relasi antar tabel dan menggambarkan secara keseluruhan konsep struktur basis data yang dirancang untuk suatu aplikasi, dapat dilihat pada Gambar 5.

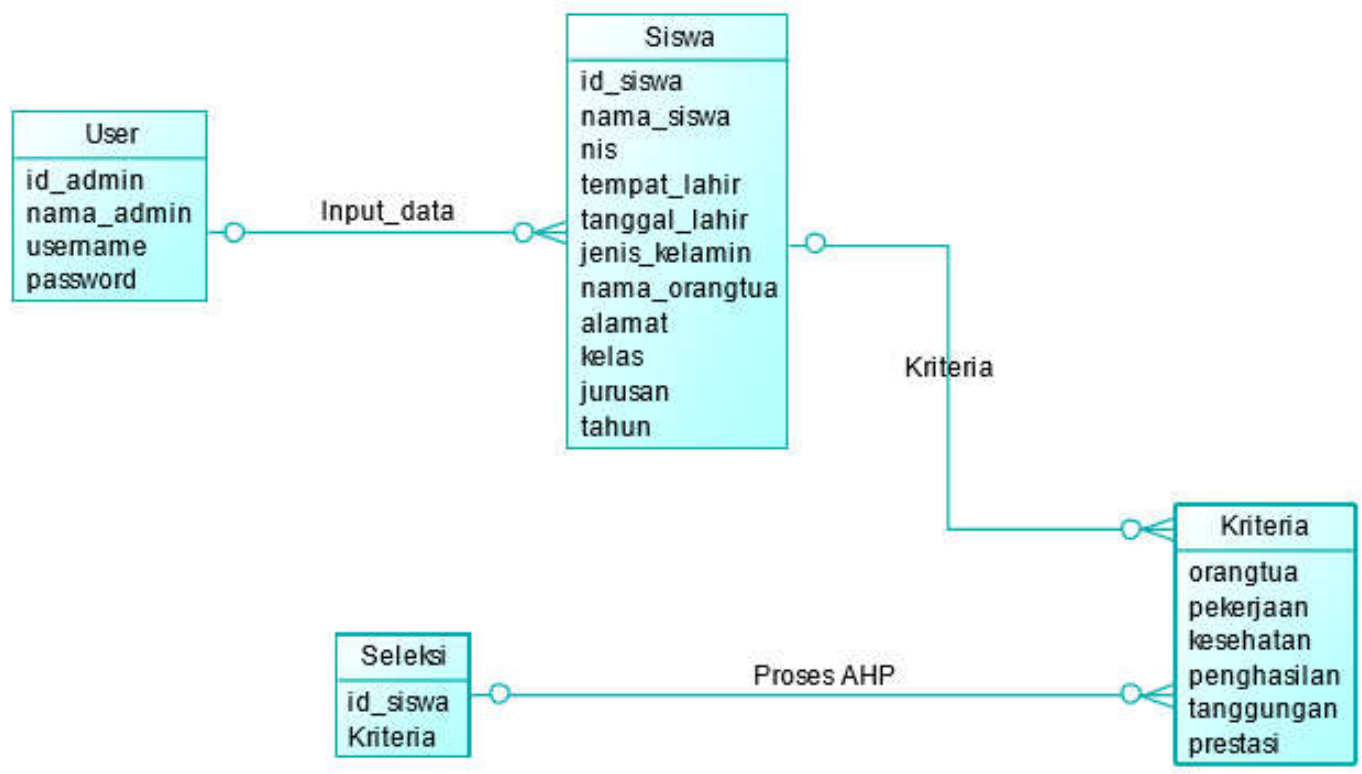

Gambar 5 CDM

\section{f. Logical Data Model (LDM)}

LDM merupakan hasil generate model dari CDM yang menggambarkan struktur basis data yang dirancang untuk membuat sistem. LDM dapat dilihat pada Gambar 6. 


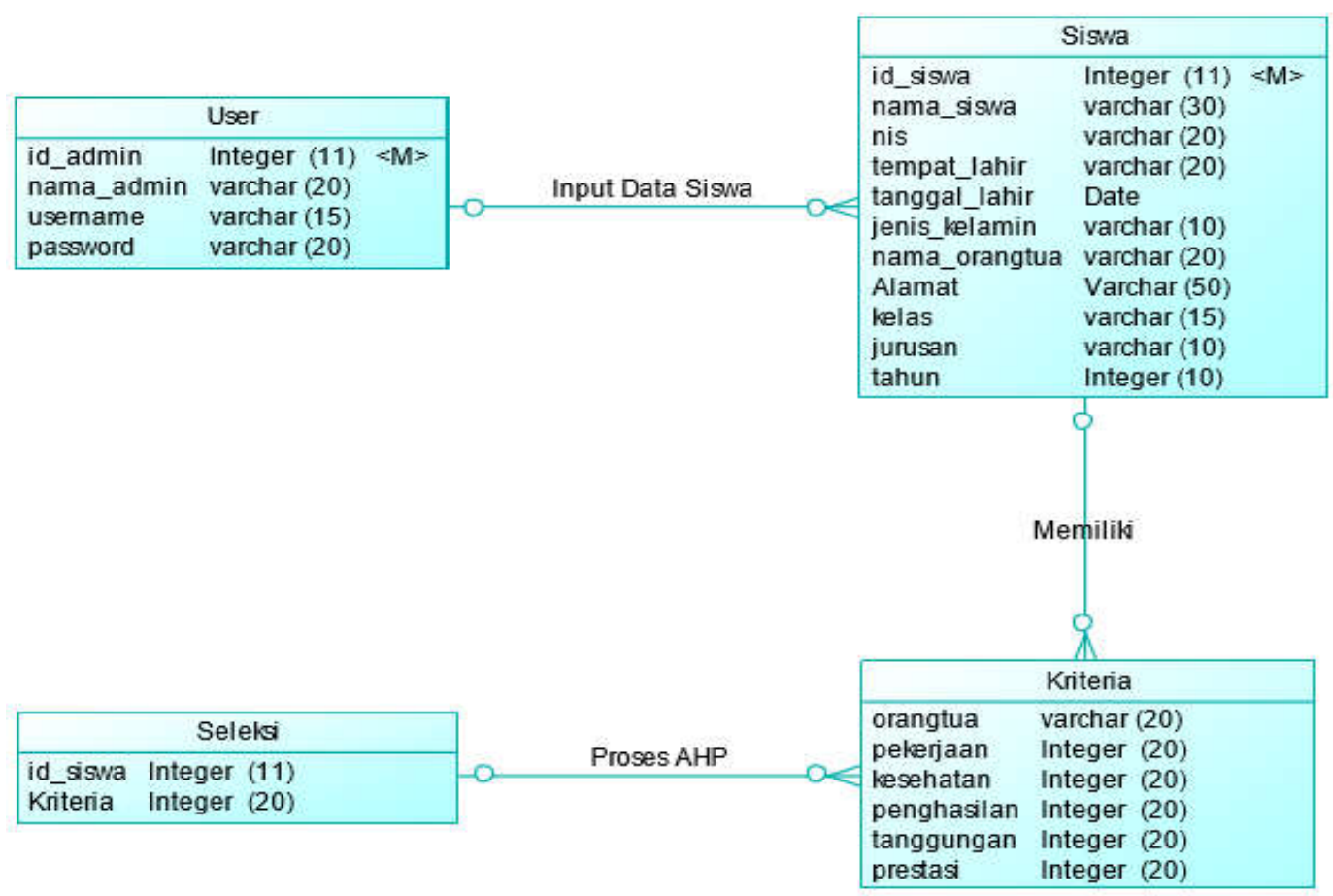

Gambar 6. LDM

g. Physical Data Model (PDM)

PDM merupakan hasil generate model dari CDM yang menggambarkan secara detil konsep rancangan struktur basis data yang dirancang untuk membuat sistem. PDM berisi tabel database beserta atribut yang terdapat pada setiap tabel, dapat dilihat pada Gambar 7.

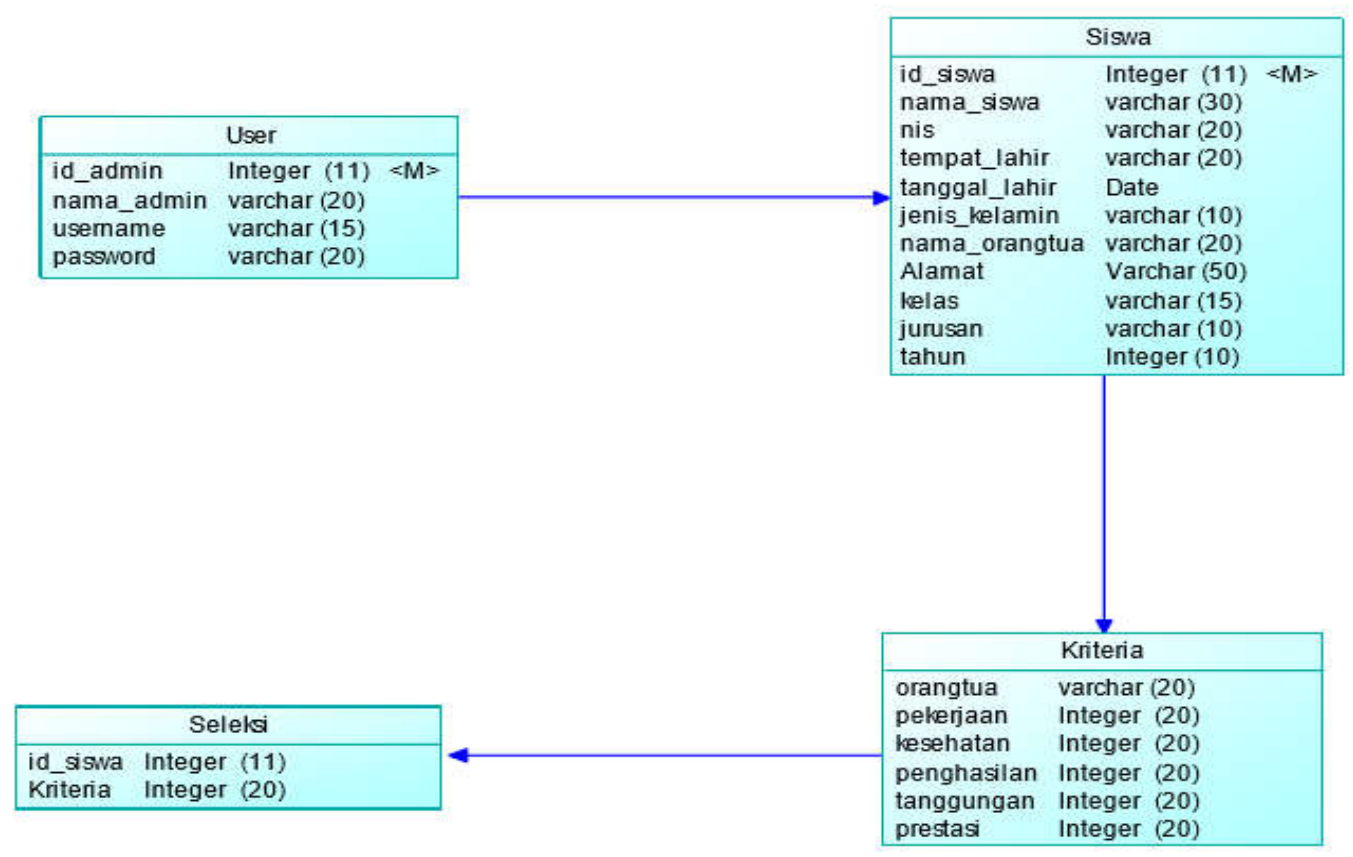

Gambar 7. PDM

\section{A. Pengertian Sistem}


Dalam sistem terdapat dua kelompok pendekatan di dalam penjelasan sistem, yaitu kelompok yang menekankan pada prosedur dan kelompok pada elemen atau komponennya. Pendekatan yang menekankan pada prosedur mendefinisikan sistem sebagai suatu jaringan kerja dari prosedur-prosedur yang saling berhubungan, berkumpul bersama-sama untuk melakukan suatu kegiatan atau untuk menyelesaikan suatu sasaran tertentu. Sedangkan pendekatan sistem yang lebih menekankan pada elemen atau komponen mendefinisikan sistem sebagai kumpulan elemen-elemen yang berinteraksi untuk mencapai suatu tujuan tertentu. Kedua kelompok definisi ini adalah benar dan tidak bertentangan, yang berbeda adalah cara pendekatannya [1].

\section{B. Pengertian Keputusan}

Dalam menghadapi segala proses yang ada disekelilingnya dan didalam dirinya, hampir setiap saat manusia membuat suatu keputusan dan melaksanakannya. Hal ini dilandasi dengan asumsi bahwa segala tindakan dilakukan secara sadar merupakan pencerminan hasil proses pengambilan keputusan dalam pikirannya, sehingga sebenarnya manusia sudah sangat terbiasa dalam membuat keputusan. Menurut Jamaes A.F Stoner, keputusan adalah pemilihan diantara alternative. Definisi ini mengandung tiga pengertian yaitu: ada pilihan atas dasar logika, ada beberapa alternative yang harus dan dipilih satu yang terbaik dan ada tujuan yang ingin dicapai dan keputusan tersebut semakin mendekatkan pada tujuan tersebut [2].

\section{Pengertian Sistem Pendukung Keputusan}

Konsep Sistem Pendukung Keputusan (SPK) atau Decision Support System pertama kali diungkapkan pada awal tahun 1970-an oleh Michael S. Scott Morton dengan istilah Management Decision System. Definisi dari Sistem Pendukung Keputusan adalah suatu sistem berbasis komputer yang ditujukan untuk membantu pengambilan keputusan dalam memanfaatkan data dan model tertentu untuk memecahkan berbagai persoalan yang tidak terstruktur [3].

Sistem Pendukung Keputusan mengacu pada suatu sistem yang memanfaatkan dukungan komputer dalam proses pengambilan keputusan. Hal ini dikemukakan oleh beberapa ahli, diantaranya Little Man dan Watson memberi definisi bahwa Sistem Pendukung Keputusan merupakan suatu sistem yang interaktif, yang membantu pengambil keputusan melalui penggunaan data dan model-model keputusan untuk memecahkan masalahmasalah yang sifatnya semi terstruktur dan tidak terstruktur [4].

\section{D.Konsep AHP}

Analytical Hierarchy Process (AHP) merupakan suatu metode yang sering digunakan untuk menilai preferensi responden yang dikaitkan dengan pembandingan bobot kepentingan antara beberapa atribut serta pembandingan beberapa alternatif pilihan [5]. AHP menerapkan model dengan hirarki fungsional dimana input utamanya adalah persepsi manusia. Dengan hirarki, suatu masalah kompleks dan tidak terstruktur dipecahkan ke dalam kelompok kelompoknya. Kemudian kelompok-kelompok tersebut diatur menjadi suatu bentuk hirarki [6]. Dengan demikian, AHP dapat digunakan untuk membuat suatu strukturisasi permasalahan yang kompleks serta konsekuensi yang ditimbulkan dari pembobotan tersebut. Interaksi beberapa faktor seringkali juga melibatkan faktor-faktor yang tidak terkuantifikasi sehingga penggunaan preferensi akan sangat membantu dalam AHP terutama untuk pemunculan sesuai skala yang telah ditetapkan. 


\section{E. Prosedur AHP}

a. Secara umum langkah-langkah yang harus dilakukan dalam menggunakan AHP untuk pemecahan suatu masalah adalah sebagai berikut: Mendefinisikan masalah dan menentukan solusi yang diinginkan, lalu menyusun hierarki dari permasalahan yang dihadapi.

b. Menentukan prioritas elemen

1. Langkah pertama dalam menentukan prioritas elemen adalah membuat perbandingan pasangan, yaitu membandingkan elemen secara berpasangan sesuai kriteria yang diberikan.

2. Matriks perbandingan berpasangan diisi menggunakan bilangan untuk merepresentasikan kepentingan relatif dari suatu elemen terhadap elemen yang lainnya.

3. Sintesis

Pertimbangan-pertimbangan terhadap perbandingan berpasangan disintesis untuk memperoleh keseluruhan prioritas. Hal-hal yang dilakukan dalam langkah ini adalah:

a. Menjumlahkan nilai-nilai dari setiap kolom pada matriks.

b. Membagi setiap nilai dari kolom dengan total kolom yang bersangkutan untuk memperoleh normalisasi matriks.

c. Menjumlahkan nilai-nilai dari setiap baris dan membaginya dengan jumlah elemen untuk mendapatkan nilai rata-rata.

4. Mengukur Konsistensi

Dalam pembuatan keputusan, penting untuk mengetahui seberapa baik konsistensi yang ada karena kita tidak menginginkan keputusan berdasarkan pertimbangan dengan konsistensi yang rendah. Hal-hal yang dilakukan dalam langkah ini adalah sebagai berikut :

a. Kalikan setiap nilai pada kolom pertama dengan prioritas relatif elemen pertama, nilai pada kolom kedua dengan prioritas relatif elemen kedua dan seterusnya.

b. Jumlahkan setiap baris.

c. Hasil dari penjumlahan baris dibagi dengan elemen prioritas relatif yang bersangkutan.

d. Jumlahkan hasil bagi di atas dengan banyaknya elemen yang ada, hasilnya disebut $\lambda$ maks.

e. Hitung Consistency Index (CI) dengan rumus:

$$
\mathrm{CI}=(\lambda \max -\mathrm{n}) /(\mathrm{n}-1)
$$

Dimana $\mathrm{n}=$ banyaknya elemen.

f. Hitung Rasio Konsistensi/Consistency Ratio (CR) dengan rumus :

$\mathrm{CR}=\mathrm{CI} / \mathrm{IR}$

Dimana $\mathrm{CR}=$ Consistency Ratio

$\mathrm{CI}=$ Consistency Index

$\mathrm{IR}=$ Indeks Random Consistency

g. Memeriksa konsistensi hierarki. Jika nilainya lebih dari 10\%, maka penilaian data judgment harus diperbaiki. Namun jika Rasio Konsistensi (CI/CR) kurang atau sama dengan 0, 1, maka hasil perhitungan bisa dinyatakan benar. [7]

\section{HASIL DAN PEMBAHASAN}

\section{A. Hasil Implementasi}




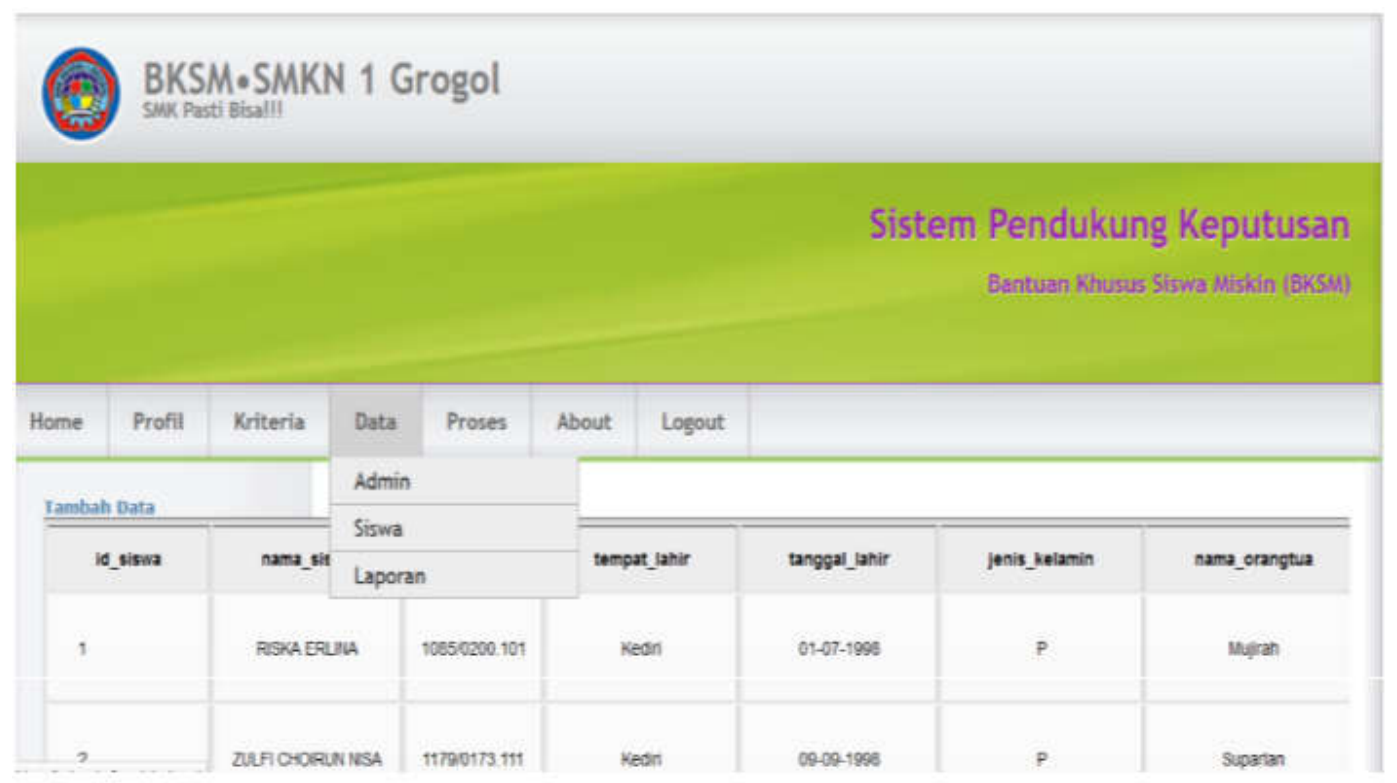

Gambar 8. Desain menu home

Pada menu data side bar berisi menu-menu data antara lain menu admin, siswa dan laporan. Pada halaman siswa menampilkan data-data siswa yang telah dimasukkan terlihat pada gambar 8 .

Menu laporan merupakan data laporan yang diambil dari data siswa, pada menu laporan terdapat menu untuk mencetak laporan pada dalam bentuk format PDF. Untuk rancangan desain laporan dapat ditunjukkan pada Gambar 9.

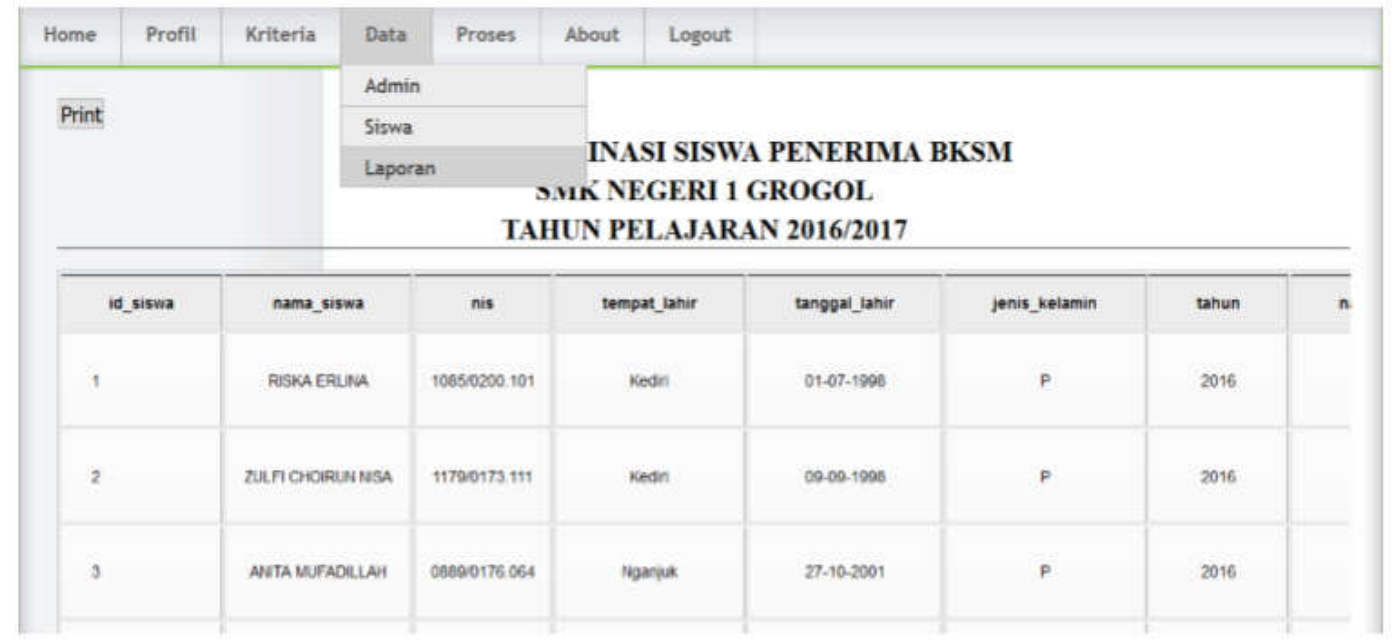

Gambar 10. Desain Output Laporan.

\section{SIMPULAN}

Berdasarkan hasil implementasi dapat disimpulkan bahwa

1. Sistem aplikasi ini diimplementasikan menggunakan metode Analytical Hierarchy Process (AHP) untuk memberikan rekomendasi dan menentukan siswa yang berhak untuk menerima Bantuan Khusus Siswa Miskin (BKSM). 
2. SPK yang dikembangkan dengan metode AHP dalam menentukan nilai bobot siswa yang berhak untuk menerima BKSM dengan cara merangking data kriteria siswa dalam proses seleksinya

\section{SARAN}

A. Saran dari peneliti untuk pengembangan selanjutnya adalah

1. Mengembangkan aplikasi ini agar bisa digunakan oleh semua sekolah yang membutuhkan system pendukung keputuan BKSM.

2. Pengembangan dengan menggunakan metode lain yang kemudian dijadikan pembanding metode mana yang lebih akurat untuk diimplementasikan.

\section{DAFTAR PUSTAKA}

[1] Jogiyanto. 2009. Analisis dan Desain Sistem Informasi.Yogyakarta : Andi Offset.

[2] Hasan, M Iqbal. 2002. Pokok-pokok Materi Statistika 1 (Statistik Deskriptif). Edisi Kedua. Jakarta : PT. Bumi Aksara.

[3] Daihani, Dadan Umar. 2001. Komputerisasi Pengambilan Keputusan. Jakarta : Elex Media Komputindo.

[4] Sutabri, Tata. 2004. Analisa Sistem Informasi. Edisi Pertama. Yogyakarta: Andi Offset.

[5] Suryadi, K., 2000, Sistem Pendukung Keputusan, Jakarta: PT. Rosdakarya.

[6] Permadi, B., 1992, AHP, Pusat Antar Universitas - Studi Ekonomi Universitas Indonesia, Jakarta.

[7] Kusrini. 2007. Konsep dan Aplikasi sistem pendukung keputusan, Yogyakarta : Andi 